\title{
ФУНКЦІОНАЛЬНА ЄВРОПЕЇЗАЦІЯ У СФЕРІ ЗАХИСТУ ПРАВ ЛЮДИНИ: НОВА РОЛЬ ОМБУДСМАНА ЩОДО MALADMINISTRATION
}

Радишевська О. Р.

У статmі автор аналізує особливості зародження іфункціонування інституту омбудсмана на європейському континенті, його визначення у європейській правовій доктрині та окреслення повноважень щодо позасудового контролю над діяльністю суб'єктів публічної адміністрації. Розкрито зміст та ознаки поняття maladministration як ключового критерію оцінки діяльності суб'єктів публічної адміністрації щодо дотримання принципів доброї (належної) адміністрації та належного врядування. Підкреслено, що на національному (в Україні, державах - членах Європейського Союзу, Ради Європи) і європейському (Європейський омбудсман) рівнях функціонує офіс омбудсмана: вони мають тотожні функції та взаємопов'язані у загальноєвропейській системі захисту прав людини - боротьбі з maladministration. Указано на особливості напрямів діяльності омбудсмана в Україні, його функціональної трансформації в умовах європеїзації адміністративного права України.

Ключові слова: європеїзація адміністративного права, омбудсман, права людини, публічна адміністрація, maladministration.

В статье автор анализирует особенности зарождения и функционирования института омбудсмена на европейском континенте, его толкование в европейской правовой доктрине и определение полномочий относительно внесудебного контроля над деятельностью субъектов публичной администрации. Раскрыто содержание и признаки понятия maladministration как ключевого критерия оценки деятельности субъектов публичной администрации по соблюдению принципов доброй (надлежащей) администрации и надлежащего управления. Подчеркнуто, что на национальном (в Украине, государствах - членах Европейского Союза, Совета Европы) и европейском (Европейский омбудсмен) уровнях функционирует офис омбудсмена: их функции похожи и связаны в общую систему защиты прав человека - борьбы с maladministration. Указаны особенности направлений деятельности омбудсмена в Украине, его функциональной трансформации в условиях европеизации административного права Украины.

Ключевые слова: европеизация административного права, омбудсман, права человека, публичная администрация, maladministration.

The author in the article analyzes the peculiarities of the emergence and functioning of the Ombudsman Institute on the European continent, its definition in the European legal doctrine and the definition of powers for non-jurisdictional control over the activities of public administration. The content and features of the concept of maladministration as a key criterion for evaluating the performance of public administration entities in respecting the principles of good administration and good governance are disclosed. It is emphasized that the Ombudsman's office is functioning at the national (in Ukraine, Member-States of the European Union, Council of Europe) and European (European Ombudsman) levels: they have identical functions and are interconnected in the pan-European system of human rights protection regarding the fight against maladministration. The author pointed out the peculiarities of the activities of the Ombudsman in Ukraine, its functional transformation in the conditions of Europeanization of the administrative law of Ukraine. Concluded that the performance of the Ombudsman's function in Ukraine in public field should be intensified in several ways: as a mechanism for external (non-jurisdictional) control over the activities of public administration and respect of the right to good administration and principles of good governance, as well as a source of recommendations for improving administrative legislation in certain administrative areas, providing institutional and methodological assistance in developing new human rights protection mechanisms, including the provision about quality public services, controlling the admission of administrative acts, protecting human rights within administrative proceedings. The powers of the Ombudsman give him the opportunity to combine the instruments of parliamentary scrutiny, judicial and non-jurisdictional control.

Key words: Europeanization of administrative law, ombudsman, human rights, public administration, maladministration.

Постановка проблеми та її актуальність. В Україні пріоритет прав і свобод людини та громадянина проголошений статтею 3 Конституції України, відповідно, їній захист - обов'язок держави. Загалом юридичне визнання людини, її прав і свобод найвищою цінністю на конституційному рівні держави передбачає кардинальну зміну характеру взаємодії між людиною і публічною владою. У демократичній державі громадянське суспільство активно впливає через свої інститути на вироблення владними інституціями політики, контролює їхню публічну діяльність, спрямовану на реалізацію виробленої політики, фактично спонукаючи чиновників служити інтересам людей [1]. Тож у сучасних умовах держава та їі інститути покликані гарантувати і захищати права і свободи людини.

На жаль, ці конституційні положення мають програмно-цільовий характер, подекуди декларативний, і втілення їх у життя $€$ вкрай важким завданням із різних причин. Щоправда, держава намагається здійснити певні кроки для вирішення цього важливого завдання. Зокрема, маємо на увазі формування нового інструменту функціонального представництва інтеpeciв - government relations (взаємодія з урядовими структурами), який охоплює майже всі сфери публічної діяльності. В його основі лежать спеціальні технології з формування взаємної довіри між бізнесом, неурядовими організаціями й органами державної влади, головна мета яких - отримати не тільки взаємовигідний, а й суспільно корисний результат [1]. Активним суб'єктом у таких відносинах є омбудсман.

Радишевська О. Р., 2019 
Аналіз останніх досліджень i публікацій. Вивченню проблематики розвитку інституту омбудсмана в умовах загальної європеїзації права присвятили свої дослідження як вітчизняні, так і вчені європейської правової доктрини. В Україні ці питання аналізувалися у працях таких представників міжнародного, європейського, конституційного, адміністративного і адміністративно-процесуального права, теорії права і державного управління, як В. Авер'янов, С. Банах, В. Бевзенко, Ю. Ващенко, І. Грицяк, С. Кикіш, В. Колпаков, В. Лутковська, О. Марцеляк, В. Муравйов, Т. Карабін, Н. Карпачова, Н. Оніщенко, А. Пухтецька, Ю. Шемшученко та інші. Проте питання зміни функціонального складника діяльності Уповноваженого з прав людини в умовах європеїзації адміністративного права не були предметом окремих наукових розробок. Про особливу роль омбудсмана в державах -членах ЄС і Ради Європи, Європейського Омбудсмана в аспекті дотримання органами публічної влади принципів належної (доброї) адміністрації обґрунтовували у своїх дослідженнях Х. Аддінг, А. Вільямс, Р. Грегорі, Ф. Гіддінгс, У. Кемпф, М. Креспо, Є. Лентовська, П. Магнетті, А. Пітерс, Л. Пейф, Д.К. Роват, І. Харден, Х.М. Хіль-Роблес тощо.

Мета статті - здійснити аналіз особливостей зародження i функціонування інституту омбудсмана на європейському континенті, його визначення у європейській правовій доктрині та окреслення повноважень щодо позасудового контролю над діяльністю суб'єктів публічної адміністрації.

Виклад основного матеріалу. Суб'єктами адміністративно-правових відносин $€$ конкретні їхні учасники (сторони), наділені законодавчо (нормативно) закріпленими правами й обов'язками, які вони здійснюють у сфері публічного управління з огляду на підстави й завдання участі в таких відносинах, організаційну структуру, а також залежно від обсягу і змісту повноважень [2, с. 121]. Головне призначення суб'єктів публічної адміністрації як представників публічної влади забезпечити належний рівень реалізації громадянами своїх прав і охоронюваних законом інтересів у публічно-правовій сфері. Це вимагає наявності значної кількості суб'єктів, які для виконання покладених на них завдань наділені різними повноваженнями, структурою і юридичними властивостями, становище яких у сфері публічного адміністрування визначається характером й обсягом їх правосуб'єктності [3]. Наголошуючи на правовому статусі окремих із цих органів, наведемо роздуми Т.О. Карабін, яка акцентує на подвійній ролі публічної адміністрації в механізмі забезпечення прав i свобод людини та громадянина, яка $\epsilon$ i «активним» суб'єктом механізму в результаті реалізації основного свого призначення - забезпечення прав громадян, i «пасивним об'єктом», коли йдеться про охорону прав громадян від порушень у сфері публічного адміністрування [4, с. 5].

Водночас, як ми вже зауважували, суб'єктом публічної адміністрації $\epsilon$ і Уповноважений Верховної Ради України з прав людини (далі - Уповноважений, омбудсман). Особливість цього інституту полягає в тому, що він не належить до жодної гілки влади, а є органом sui generis, тобто особливого роду, і діє лише йому властивими засобами і методами [5, с. 59].

Згідно із Законом України «Про Уповноваженого Верховної Ради України з прав людини» від 23.12.1997 [6] він на постійній основі здійснює парламентський контроль за додержанням конституційних прав і свобод людини та громадянина, а також захист прав кожного незалежно від інших державних органів і посадових осіб. Саме для пришвидшення процедури усунення порушень прав людини та їх недопущення в майбутньому в Україні, за прикладом західноєвропейських держав, створено інститут омбудсмана. Однак обізнаність громадян про свої права та шляхи поновлення порушених прав все ще залишається низькою. Про це свідчать численні звернення, які надійшли до Секретаріату Уповноваженого і яких у 2018 році було понад 25 тисяч [7, с. 2]. Отже, в Україні Уповноважений $є$ спеціальним органом державної влади, призначений парламентом, що здійснює захист прав людини у всіх сферах іï життєдіяльності: дотримання принципів доброї (належної) адміністрації та боротьби з maladministration.

Нагадаємо, що поняття “maladministration” у європейському адміністративному праві $\epsilon$ недоокресленим: виникають проблеми як під час перекладу цього терміну на українську (іншу європейську) мову, так і щодо аналізу його генезису. Так, у польській і українській адміністративно-правовій літературах зустрічаємо: "niewtaściwe (zte) administrowanie" - невластиве (погане) адміністрування, "złe zarządzanie" - погане управління, "wadliwa dziatalność" - діяльність із недоліками, "niewtaściwa działalność" - невідповідна діяльність, "nieudolność administracji” - нездібна адміністрація, “zła administracja” - погана (неналежна) адміністрація. Однак можемо стверджувати, що названі терміни знаходяться у логічно-мовленнєвому зв'язку, характеризують функціональність публічної адміністрації та вказують на їі якість і недоліки [8, с. 53-58].

щодо розкриття змісту цього явища та ролі у ньому омбудсмана, то необхідно звернутися до зародження концепції доброї (належної) адміністрації - антоніма maladministration - організації правового захисту контролю за публічною адміністрацією в Англії. Для цих цілей було запроваджено посаду Комісара парламенту у справах адміністрації (Parliamentary Commissioner for Administration). У 1961 році англійська секція Міжнародної асоціації юристів (IBA) як результат дворічної роботи опублікувала звіт, у якому запропонувала адаптувати скандинавську модель омбудсмана до потреб Великобританії [9, с. 11]. Взірцем мав стати інститут норвезького омбудсмана (Parlamentarny Ombudsman), однак критерії контролю повинні були бути інші [10, с. 285]. Основною функцією британського Омбудсмана у 1967 році було визначено розгляд скарг приватних осіб щодо поганого адміністрування (maladministration) [10, с. 293], захист прав людини у відносинах з публічною владою, якщо їй було завдано шкоду з причин несправедливого відношення до нього поганою адміністрацією [9, с. 46].

Однак і тут законодавець не надав визначення maladministration, лише вказав, що воно буде розкрите у судовій та адміністративній практиках; позасудовий контроль буде стосуватися діяльності, що характеризується упередженістю, неуважністю, затримками у виконанні завдань, некомпетентністю, повільністю, відходом від усталеної практики, сваволею (перевищенням дискреції). У майбутньому такий перелік ознак публічної адміністрації назвуть Каталогом Кросмана (Crossman catalogue) [11, с. 466]. 
Зазначимо, що сьогодні більш ніж у 120 країнах світу існує посада омбудсмана [12, с. 221]. Щоправда, у різних країнах вона має різну назву: у Франції - Посередник (медіатор) Французької Республіки, у Великобританії - Парламентський комісар у справах адміністрації, в Іспанії та Румунії - Захисник народу, в Албанії - Адвокат народу, у Грузії - Народний Захисник, у Словенії та Чехії - Державний правозахисник, у Молдові - Парламентські адвокати, у Російській Федерації, Індонезії, Таїланді, Республіці Корея - Уповноважений із прав людини, у Литві - контролери Сейму, в Естонії - Канцлер юстиції та інші [13]. Офіційна назва інституту омбудсмана в Польщі - Речник з громадянських прав [14], а в Україні - Уповноважений Верховної Ради України з прав людини [6].

У вітчизняних джерелах $\epsilon$ різні підходи до визначення інституту омбудсмана, що розкривають його функціональні обов'язки. Це і посадова особа держави, яка здійснює контроль за додержанням конституційних прав і свобод людини [15], і служба, що безпосередньо займається захистом прав і законних інтересів людини, пов'язаних з відносинами з органами виконавчої влади і управління [16, с. 14], і допоміжний та самостійно функціонуючий державний спеціалізований орган, що володіє нетрадиційними методами дослідження та реагування на факти порушень прав і свобод людини посадовими особами органів незалежно від форми власності державної та публічної влади [17, с. 47].

Класичне визначення омбудсмана для європейської правової доктрини надає англійський дослідник Д. K. Роват (D.K. Rowat): по-перше, це незалежна і непартійна посадова особа, що призначається законодавчою владою і контролює адміністрацію; по-друге, він розглядає індивідуальні скарги громадян на несправедливу публічну адміністрацію і maladministration; по-третє, він має право розслідувати, критикувати та оприлюднювати результати своєї діяльності, але не навпаки, щодо дій (бездіяльності) адміністративних органів [18, с. 49]. Аналогічне за змістом визначення міститься і в Енциклопедії «Брітаніка» (“Britannica”): це уповноважений законодавчого органу, який покликаний розслідувати скарги громадян на бюрократичні зловживання [19].

Отже, у сучасному світі омбудсман - це державний службовець найвищого рангу, який призначається на посаду зазвичай парламентом і покликаний захищати права людини у всіх сферах життєдіяльності. Незалежно від правової системи, моделі омбудсмана, його основною функцією був і залишається контроль за діяльністю національної публічної адміністрації.

Зазначимо, що, крім національного рівня, інститут омбудсмана діє також на наднаціональному (європейському) рівні. Так, відповідно до статей 24, 228 Договору про функціонування Європейської Спільноти [20] діє інститут Європейського Омбудсмана (англ. European Ombudsman, фр. - Médiateur européen, нім. Europäischer Bürgerbeauftragter), основним завданням якого визначено поширення концепції європейського громадянства та боротьбу з maladministration - недотриманням інститутами і установами ЄС законодавства у відносинах з приватними особами у сфері адміністрування - це його raison d'etre [21, с. 699]. Адже публічна адміністрація ЄС повинна мати більш «людське обличчя» і бути якісною [22, с. 6]. Хоча ідеї ство- рення омбудсмана на наднаціональному рівні виникли ще у середині 1970-х років, у межах течії у Західній Європі «Омбудсманія», проте реалізувати іï у ЄС вдалося лише у 1992 році під час підписання Договору про $\in C$ [23, с. 426].

Цікавим $\epsilon$ той факт, що у європейському адміністративному просторі уперше вжив термін "maladministration" Омбудсман ЄC у Рапорті за 1997 рік: "Maladministration - це погана або «невдала» адміністрація; вона виникає тоді, коли публічний орган не виконує свої функції відповідно до правил чи принципів, які уповноважують його до дій, коли не дотримано принципів доброї (належної) адміністрації, коли порушуються права людини» [24]. Як наслідок, у 1998 році Європейська Комісія схвалила таке тлумачення, яке потім лягло в основу формулювання права на добру (належну) адміністрацію, закріпленого статтею 41 Хартії основоположних прав ЄС (2000) [25]. Статтею 43 цього акту передбачено право громадян ЄC і осіб, що офіційно зареєстровані у державі-члені, звертатися зі скаргами до Європейського Омбудсмана у випадках неналежного виконання функцій установами та інституцій ЄС, за винятком скарг на рішення Суду Справедливості і суду першої інстанції під час виконання ними судових функцій.

Позасудовий захист омбудсманом права на добру (належну) адміністрацію передбачає відповідь на скаргу приватних осіб або проведення слідства за власною ініціативою. Водночас інституції ЄС зобов'язані надавати йому будь-яку інформацію і доступ до відповідних офіційних документів. Установивши факти порушень, він повідомляє установу, що перевіряється про виявлене порушення, і надає свої рекомендації щодо його усунення. Установі-порушнику надається строк три місяці на те, щоб дати детальну відповідь, після чого омбудсман надсилає остаточний звіт до Європейського Парламенту і повідомляє про результати слідства заявника [26, c. 680].

У рапорті Європейського Омбудсмана за 2018 рік Е. O’Рейлі (E. O’Reilly) указує, що до їі Офісу звернулися 17996 осіб, із них 14596 отримали відповідь через Інтернет, 1220 звернень здійснено у формі запитів, a 2180 - скарги. Як наслідок, розпочато 490 розслідувань, із них 482 - за скаргами приватних осіб і 8 - за власною ініціативою. Більшість запитів стосувалися Європейської Комісії $(58,2 \%)$, агентств $Є С(8,8 \%)$, Європейського Парламенту $(6,1 \%)$, Європейського офісу з підбору персоналу (EPSO) (4,7\%), Європейської служби зовнішньої дії (EEAS) $(4,7 \%)$, Європейського інвестиційного банку (3,3\%), Європейського офісу з боротьби 3 шахрайством (OLAF) (2,8\%), інших установ $(11,4 \%)$ [27].

Водночас предметом таких скарг було недотримання суб'єктами публічної адміністрації ЄС принципів прозорості, підзвітності та доступу до інформації та офіційних документів $(20,6 \%)$, культури надання публічних послуг $(16,8 \%)$, поваги до процедурних прав $(16,5 \%)$, інші питання стосуються етичних питань, участі громадськості у прийнятті рішень ЄС, поваги до основоположних прав, належного використання дискреційного розсуду, належного фінансового управління тендерами, грантами та контрактами ЄС, підбору персоналу та належного управління питаннями персоналу $€ C$. Тоді як об'єктами стратегічних запитів Європейського омбудсмана було: лікування людей з обмеже- 
ними можливостями в рамках Спільної схеми страхування на випадок хвороби; про доступність вебсайтів Європейської Комісії для осіб з обмеженими можливостями; щодо діяльності Європейського агентства з лікарських засобів; щодо персоналу $€ C$ та відповідальності за законотворчу діяльність Європарламенту, а також низки стратегічних ініціатив: використання мов на публічній службі, політики боротьби з домаганнями на публічній службі, захисту дітей під час міграції, щодо правил «оборотних дверей» (“revolving doors") у різних установах і органах ЄC [27].

Проте необхідно підкреслити, що жодна з інституцій або органів ЄС не наділена такими повноваженнями, як Європейський Омбудсман: у них немає такої технічної гнучкості у реагуванні на потреби розвитку і вдосконалення права $€ С$, вони не спроможні здійснювати відповідний контроль над публічною адміністрацією ЄС і пропонувати механізми реформування у публічно-правовій сфері [28, с. 40]. У цьому вбачається особлива і виняткова роль омбудсмана.

Так, наприклад, для ефективного реагування на порушення права на добру (належну) адміністрацію на території ЄС Європейським омбудсманом із власної ініціативи у 1999 році був підготовлений проєкт документу, що потім ліг в основу Європейського кодексу належної адміністративної поведінки 2001 року (The European Code of Good Administrative Behaviour) [29]. Незважаючи на рекомендаційний характер документу, адже він $\epsilon$ актом soft law, він активно впливає на підготовку законопроєктів про публічну службу у державах - членах ЄС, адміністративні процедури, став основою для прийняття етичних кодексів поведінки публічних службовців окремих інституцій ЄС, зокрема Європейської Комісії (Code of Good Administrative Behaviour for staff of the European Commission in their Relations with the Public).

Таким чином, цей документ визначив, по-перше, що громадяни повинні очікувати від публічної адміністрації, i, по-друге, як публічні службовці повинні виконувати свої функції по відношенню до них. Сьогодні Європейський омбудсман продовжує роботу щодо поширення принципів адміністративних процедур, закладених у Кодексі, як у ЄС, так і поза його межами, хоча 6 у формі внутрішньо організаційного акту [22, с. 18].

Прикладом такої роботи $є$ проєкт ЄС Twinning «Впровадження кращого європейського досвіду з метою посилення інституційного потенціалу Секретаріату Уповноваженого Верховної Ради України з прав людини для захисту прав і свобод людини", реалізація якого відбувалася в України у 2017-2019 роках литовсько-австрійським консорціумом [30]. Метою проєкту було визначено забезпечення ефективного попередження і реагування на порушення прав людини шляхом посилення інституційного потенціалу інституції омбудсмана як дієвого механізму парламентського контролю за дотриманням прав і свобод людини на національному рівні, з урахуванням кращих європейських практик, посилення ролі омбудсмана в Україні, зокрема, як позивача у адміністративному судочинстві та суб'єкта законодавчої ініціативи. Як результат експертами було підготовлено низку проєктів: Кодекс належної адміністративної поведінки; Закони України «Про захист персональних даних»; «Про Уповноваженого Верховної Ради України з прав людини»; «Про реалізацію принципу рівного ставлення»; «Про доступ до публічної інформа- ції» та інші. Уважаємо, що така діяльність інституції ЄС $\epsilon$ прикладом непрямої європеїзації адміністративного права України.

Висновки. В умовах демократії державне управління описується не як односторонній вплив, а як взаємовплив, коли суб'єкт управління не тільки посилає до об'єкта управління певні специфічні імпульси впливу, а й фіксує реакцію на них. Навіть більше, не можна забувати, що в контексті взаємозв'язку публічної адміністрації і демократії загальним суб'єктом управління $\epsilon$ сам народ, який формує органи державної влади і впливає на визначення основних цілей та пріоритетів державно-управлінської діяльності [31, с. 26-27]. 3 огляду на це проблеми взаємодії громадянина з публічною адміністрацією щодо реалізації його прав і свобод розглядаються крізь призму інституту публічних послуг, що охоплює багато сфер, насамперед освіти, охорони здоров'я, соціального захисту. Розвиток і вдосконалення названого інституту $є$ одним з пріоритетних напрямів політики модернізації нашої держави. Будучи елементом загального механізму захисту прав громадян, їх безпосередня реалізація водночас $\epsilon$ самостійною стадією цього процесу, що має власний механізм, покликаний забезпечувати ефективність діяльності публічної адміністрації.

Отже, виконання функції омбудсмана в Україні має активізуватися у декількох площинах: як механізм зовнішнього (позасудового) контролю за діяльністю публічної адміністрації та дотримання права на добру (належну) адміністрацію і принципів належного врядування, а також як джерело рекомендацій щодо вдосконалення адміністративного законодавства у певних сферах, надаючи інституційну та методичну допомогу у розробці нових механізмів захисту прав людини, зокрема надання якісних публічних послуг, дотримання принципів прийняття адміністративних рішень, реалізації права особи на захист порушеного права в порядку адміністративного судочинства.

\section{Література}

1. Інструменти та механізми вироблення й впровадження публічної політики в Україні. Укрінформ. 2019. 3 черв. URL: https://www.ukrinform.ua/rubric-other_ news/2713805-instrumenti-ta-mehanizmi-viroblenna-jvprovadzenna-publicnoi-politiki-v-ukraini.html (дата звернення: 20.02.2020).

2. Загальне адміністративне право : підручник / І.С. Гриценко, Р.С. Мельник, А.А. Пухтецька та ін.; за заг. ред. І.С. Гриценка. Київ : Юрінком Інтер, 2017. 568 с.

3. Свистович Р.С. Суб'єкти публічної адміністрації: сучасний вимір. International scientific journal "Internauka" Series: "Juridical Sciences". URL: http://www.inter-nauka. com/magazine/law/ (дата звернення: 20.02.2020).

4. Карабін Т.О. Розподіл повноважень публічної адміністрації (доктринальний адміністративно-правовий аналіз) : автореф. дис. ... д-ра юрид. наук : 12.00.07. 3., 2016. 34 c.

5. Карабін Т.О. Розподіл повноважень публічної адміністрації : монографія. Ужгород : Ґражда, 2016. 296 с.

6. Про Уповноваженого Верховної Ради України з прав людини: Закон України від 23.12.1997 № 776/97-ВР. База даних «Законодавство України» / BP України. URL: https: / / zakon.rada.gov.ua / laws / show / 776 / 97-\% D0\%B2\%D1\%80 (дата звернення: 20.02.2020).

7. Щорічна доповідь Уповноваженого Верховної Ради України з прав людини у 2018 році. Про стан додержання та 
захисту прав і свобод людини і громадянина в Україні. URL. http: //www.univ.kiev.ua/content/upload/2019/-697223196. pdf (дата звернення: 20.02.2020).

8. Радишевська О. Malaadministration jako nowa kategoria prawa administracyjnego Ukrainy, Правові засади європейської та євроатлантичної інтеграції України: досягнення та перспективи: матеріали учасників II-ої наук. практ. конф. (Львів, 23.11.2018), Л., 2018, с. 53-58.

9. Addink G. H. The Ombudsman as the fourth power. On the foundations of Ombudsman law from a comparative perspective. Judicial Lawmaking and Administrative Law ; ed. F. Stroinka, E. van der Lindena. Antwerpen, 2005, 285 p.

10. Pollard D., Parpworth N., Hughes D. Constitutional and administrative law; Ext. with materials. Oxford, 2007. 399 p.

11. Bar L. Nowe instytucje $w$ angielskim prawie administracyjnym. "Państwo i Prawo". 1968. T. 3. S. 466-489.

12. Righting Wrongs. The Ombudsman in Six Continents / ed. by Gregory R., Giddings P. Amsterdam, International Institute of Administrative Sciences 2000. 502 p.

13. Деятельность омбудсменов в различных странах мира. Европейский омбудсмен. URL: http: / / euro-ombudsman.org/ombudsmen_activities / mass-media/kto-takoy-ombudsmen (дата обращения: 20.02.2020).

14. O Rzeczniku Praw Obywatelskich : Ustawa RP. Dziennik Ustaw. 2001, Nr 14, poz. 147 URL. https://www.rpo.gov.pl/ $\mathrm{pl} /$ content/ustawa-o-rpo (data dostępu 20.02.2020).

15. Кикіш С. Омбудсмен як альтернативний спосіб захисту прав людини: міф чи реальність? Юридична газета online. 2018. 4 груд. № 49 (651). URL: http: / / www.p-partners.com/storage / files / 2019. 04-12/49_651_ombudsmen_yak_alternativniy_sposib_ zahistu_prav_lyudini_mif_chi_realnist.pdf (дата звернення: 20.02.2020).

16. Банах С.В. Функції омбудсманів у сучасному світі: порівняльно-правове дослідження : дис. ... канд. юрид. наук: 12.00.02. Маріуполь, 2014. 236 с.

17. Марцеляк О.В. Конституційно-правовий статус інституту омбудсмана: світовий досвід та українська модель : дис. ... д-ра юрид. наук : 12.00.02. Одеса, 2004. 472 c.

18. Rowat D. Administrative Secrecy in Developed Countries (Studies in Administrative Procedure). Columbia University Press 1979. 299 p.

19. Encyclopedia Britannica. Ombudsman. URL. https://www.britannica.com/topic/ombudsman (date of access 20.02.2020)

20. Договір про функціонування Європейської Спільноти : міжнар. док. від 25.03.1957. Європейське економічне співтовариство. Консолідована версія. URL: https://zakon.rada.gov.ua/laws/show/994_ (дата звернення: 22.02.2020).
21. Peters A. The European Ombudsman and the European Constitution. Common Market Law Review. Netherlands, Kluwer Law International. 2005. № 42. P. 697-743.

22. The European Ombudsman. Annual Report 2005. The European Ombudsman 2006. URL: file:///C:/Users/Alex/ Downloads/rap05_en.pdf (date of access 20.02.2020).

23. Pino M., María A. The European Ombudsman in the framework of the European Union. Revista Chilena de Derecho. Vol. 38. № 3. 2011. P. 421-455.

24. The European Ombudsman. Annual Report 1997. The European Ombudsman 1998. URL. https: / www.ombudsman.europa.eu/en/publication / en/3447 (date of access 20.02.2020)

25. Charter of Fundamental Rights of the European Union. European Parliament, the Council and the Commission. URL. https://www.europarl.europa.eu/charter/pdf/text_ en.pdf (date of access 20.02.2020).

26. Magnette P. Between parliamentary control and the rule of law: the political role of the Ombudsman in the European Union. Journal of European Public Policy. 2003. № 10. P. 677-694.

27. Report on the activities of the European Ombudsman - annual report 2018. European Parliament. URL. http: / / www. europarl.europa.eu/doceo/document/A-92019-0032_EN.html (date of access 20.02.2020).

28. Bonnor G. The European Ombudsman: a novel source of soft law in the European Union. European Law Review, 2000. Vol. XXV. p. 39-49.

29. The European Code of Good Administrative Behaviour. URL: http://www.ombudsman.europa.eu/resources/code. faces (date of access 20.02.2020).

30. Впровадження кращого європейського досвіду з метою посилення інституційного потенціалу Секретаріату Уповноваженого Верховної Ради України з прав людини для захисту прав і свобод людини: Проєкт Twinning. URL: http://www.twinning-ombudsman.org/uk/ (date of access 20.02.2020).

31. Демократичні засади державного управління та адміністративне право : монографія / кол. авт.: Ю.С. Шемшученко, В.Б. Авер'янов, О.Ф. Андрійко, І.О. Кресіна, В.П. Нагребельний та ін. ; за заг. ред. д-ра юрид. наук. Київ : Юрид. думка, 2010. 496 с.

Радишевська О. Р., https://orcid.org/0000-0002-3262-7487 кандидат юридичних наук, доцент кафедри адміністративного права юридичного факультету

Київського начіонального університету імені Тараса Шевченка, суддя Касаційного адміністративного суду у складі Верховного Суду 